\title{
Students' Views about Enriched Summer Camp for High School Students
}

\author{
Ayşin Kaplan-Sayı ${ }^{{ }^{*}}$ \\ ${ }^{1}$ Istanbul Aydin University, TURKEY
}

Received 12 May 2017 • Revised 11 September 2017 • Accepted 27 September 2017

\begin{abstract}
In New Era high level thinking skills, personal development and network could be demonstrated as the keys of life success. Because of this, enrichment camps became very popular. This paper presents the layout and results of a summer camp project that aims to promote insight on high school students towards many disciplines of science, culture, develop their self-confidence and help high school students to choose the most appropriate job for themselves. The students introduced university lectures from different branches such as; molecular biology and genetics, solid works, international relations, forensic psychology, nano materials and $\mathrm{x}$-ray analyses etc. The the core body of knowledge has been enriched with applications in a laboratory environment. The students have been assigned to learn by experience with the help of hands-on project design activities during the project. Drama, cultural tours, seminars, meetings, sports, dance and yoga have been used as social activities for introducing campus life and facilities. In addition to these, the students have also been informed about the importance of discovering their interests and talents within the scope of this camp. This program was in operation in summer term of 2015-2016 academic year at Istanbul Aydin University. The students were given semi-structured interview and the data were analyzed through descriptive analysis. The sample of the study consists of 39 students coming from different state and private schools in different cities. The results indicated that summer camp increased academic motivation, awareness of life and career also the socialization skills of the participants. Besides, the students stated that they were able to be recognize of a university, university environment, scientists and different professions.
\end{abstract}

Keywords: enrichment in education, summer high school camp, Istanbul Aydin University

\section{INTRODUCTION}

Today, technology is improving at full speed, information can be reached in a matter of minutes while countries and societies are getting closer to each other due to globalization. This makes new generation well-equipped with information and it forces the educational environments to keep up this change at the same time. Training programs and educationalists, the first addressees for the issue, should revise and change themselves in line with the needs of new generation. New era also requires individuals to gain a number of high level reasoning and creative skills, develop personality and constituting a network constantly. In order to both improve these skills and meet the needs of new generation, some new educational approaches and strategies are being developed. It is possible to claim that the most commonly and efficiently use strategy is enrichment strategy. Schiever and Maker (2003) define enrichment as enhancing the content beyond the program itself by diversifying educational opportunities and programs. It has been empirically demonstrated in several studies that enrichment programs are effective in general. They further develop productivity and creativity, they enhance achievement and mastery motivation and they improve positive self-confidence and active self-regulation. Even short-term summer courses can have these

(C) Authors. Terms and conditions of Creative Commons Attribution 4.0 International (CC BY 4.0) apply. 


\section{Contribution of this paper to the literature}

- This paper draws a frame about the aims of an enrichment program for high school students

- Promotes insight for the researchers who design an enrichment course for high school students

- Clarify the expectations and gainings of high school students who participated a high school enrichment camp

positive effects and, as Neber and Heller (1997) have shown for the German School Students Academy in a longitudinal study, positive effects on self-concept, study interests, and work habits can still be demonstrated 3 to 5 years after participation (cited Hany \& Grosch 2007).

In enrichment strategy, there are two kinds of enrichment. One of these is horizontal enrichment which is diversifying course, subjects and activities and the other one is vertical enrichment made by changing the content of training to make it more complicated and improving high level thinking skills. Among these, horizontal enrichment is more frequently used since it is more practical. This sort of enrichment is used by school and universities by adding courses to the programs such as astronomy, archaeology, sculpture and plastic arts or by organizing semester programs or summer camps. Summer camp is widely preferred as a way of horizontal differentiation due to the flexibility of summer season.

Summer camps are made in different forms with different aims and contents for example, for those having medical problems (Westervelt, Johnson \& Murril 1998) for those having low academic performance and wishing to learn a foreign language (Dahl., Hofstad \& Salomon 2013) for different groups with the aim of discovering and improving skills (Das 1994; Jeffrey et al. 2003; Bhattacharyya 2011; Allen et al. 2011), for specific groups (Hirca 2013; Shabi \& Ansari 2001) and disciplines (Richards, 2011). Summer camps serving for different aims are made in general for science and environmental awareness or for raising individual awareness of high school students and career orientation (Tekbiyik, Seyihoglu, Vekli \& Konur 2013; Marulcu, Saylan \& Guven 2014; Konur, Seyihoglu, Sezen \& Tekbiyik 2011; Celik 2012; Foster \& Shiel-Rolle 2011; Knox, Moynihan \& Markowitz 2003; Es 2016; Smith, Steel \& Gidlow 2010; Fields 2009; Shacter \& Jo 2005; Doerschuk, Liu \& Mann, 2007).

One of the examples which related to science; aimed to give high school students opportunity to collaborate with their peers, in a university setting while building and programming of robots. The program lasted three weeks and the participants learned the basic knowledge necessary to program a robot. In conclusion the survey results shows that attendance to the camp contributed to students learning related to STEM, increased interest among the students especially in the sciences; biology, chemistry, physics and had a significant effect on the enrolment of participating students to that university (Álvarez\& Balaguer, 2017). Another research explored the efficacy of a U.S Summer science camp to demonstrate improved understandings about scientific inquiry (SI) among a group of gifted Taiwanese students $(n=19)$ in grades 8 and 9. Participants were completing an 80 -hours summer science camp at a Midwestern U.S. university. The main objective of this camp was to provide participants with an intensive program focusing on science content, nature of science, and scientific inquiry. The camp included inquiry activities designed to provide hands-on experiences. Physical and life science-based content was targeted, and understandings about scientific inquiry were positioned as an explicit theme connecting these experiences. The results of this study suggest only modest changes in students' understandings about scientific inquiry. However, despite the short duration of the intervention and the small sample size, there was evidence of participants' growth toward more informed understandings for four aspects of scientific inquiry (Antink-Meyer et al. 2014). Sowells et al. (2016) also examined whether a Technology summer camp stimulate the interest of female high school students from low income. The camp designed as short-term intensive, based on hands on experiences and aimed to increase the number of low income female students who pursue degrees in technology disciplines at collegiate level. The results of the study indicated that not only did the program stimulate interest in the technology profession, it also introduced female students to new and innovative technology concepts while supporting and improving technology and leadership skills.

In Turkey generally summer camps are organized around robotics, coding and engineering and aimed to research their effects on student's career choices as well. Ayar et al. (2013) organized a two-week robotics summer camp for high school students and they presented computer programming course, basic electronics course and proteus, pic and microC training courses. Also, the students attended other extracurricular activities. According to their findings via this summer camp participating students gained first hand and original engineering design experience and outreach programs offered to have chance to get practical engineering work to high school students. Another research also aimed to raise awareness for computer engineering and digital electronics engineering and promote insight on high school students towards computer hardware and its mathematical background with 35 10th grade high school students. It lasted five days and quizzes, daily virtual classroom sessions, professional tendency detection scale, project evaluation forms, general discussion (focus group interview) session and parents' feedbacks have been used for the evaluation of the project outcomes. The project personnel's, students' and 
parents' overall positive feedback about the project found encouraging for working on enhanced versions of this kind of camps in the following years. According to the findings students thought that virtual classroom sessions and general discussion session provide them a chance to explain their ideas and all the analyses demonstrated students learned the basic concepts of computer engineering and digital electronics with hands on experiments and creative-friendly environment. This project findings parallel to other studies' findings which increased students' motivation and awareness about engineering (Ciloglu et al., 2017).

When the literature examined, especially the summer camps organized for high school students in Turkey are made only for career orientation or for increasing awareness on some focused career or field such as engineering, robotics, foreign language etc. But in our study, we focused many disciplines for enriching students' vision, culture and help them to know themselves more; as well as contributing to their personal development and having a network and choosing the rightest career. This underlines the importance of our study. Enrichment courses experiences can have long-term effects on students affect, cognition, motivation (Saß, Wittchen, \& Zaudig, 1996) and in the long run life success. Another mechanism of development enrichment courses might operate through is the change of self-efficacy. Direct experience of high-level performance may provide students with a strong sense of self-efficacy, which helps them to pursue and to master further challenges (Bandura, 1987). Though a number of universities organize summer camps, there has been very few academic study on the evaluation of these practices in Turkey's context. To fill in this gap, the present study aims to investigate the perspectives of high school students who were exposed to enriched education in summer camp at a university in Turkey.

\section{METHODOLOGY}

\section{Research Design and Participants}

The present study conducted with the aim of examining the views of high school students about the enriched summer camp program. For announcing the camp and program's details a web page and a Facebook page is opened. The lessons and their contents presented on the web page. The web page can be reached from the link; liseyazokulu.aydin.edu.tr. For enriching learning environment, computers, projectors, different kinds of microscopes also real-life examples and hands on experiments were used.

This research being a "basic qualitative study" was a specific research project to "seek to discover and understand a phenomenon, a process, or the perspectives and world views of the people involved" (Merriam, 1998). Data collected primarily through interviews but included observations and documents. The findings of this research will become a combination of description and analysis. This analysis based on theoretical frame made obvious through the study as well as recurring patterns found in the interview data (Merriam, 1998).

\section{Participants}

When Ministry of Turkish National curriculum analyzed because of the readiness the students who completed 9 th grade and become 10th,11th and 12th grade; found as the most appropriate group so the 10th, 11th and 12th grades are the focus for the study. The students were chosen from volunteers and they were reached by communicating all Anatolian high schools and private high schools in Istanbul. As a result, 39 students whose ages ranging between 15 and 18 from 7 different high schools are chosen. 20 females and 19 males participated to study. Project team constituted 23 lecturers and four supervisors. All lecturers studied in different times but supervisors are included in two-weeks time from beginning to the end of the camp.

\section{Data Collection Tools}

In the present study, the participants were given the researcher-designed semi-structured interview titled "The Perspectives on Istanbul Aydin University High School Summer Camp" which was comprised by the researcher. The interview was sent to four specialists to ensure construct validity. It consisted of 14 rating scale and 8 openended questions. Data handled from the participants are organized as themes and codes which analyzed by means of descriptive analysis. The results were presented in percentages and frequencies also supported by the thoughts of participants. The questions presented at the interview were;

\section{Implementation}

The program lasted for two weeks in summer term of 2015-2016 academic years in Istanbul Aydin University. It was implemented as an enrichment consisting of nine different courses at different fields (Turkish high school educational system presented three different working spaces to students which focused on social sciences, mathnatural sciences and linguistic-math sciences. The courses organized according to these working spaces). The 
Table 1. 14 Rating scale Questions used in the interview

\section{Questions}

(1: Strongly disagree, 5: Strongly agree)

$\begin{array}{llllll}1 & 2 & 3 & 4 & 5\end{array}$

1. The content of the program cohered with its introduction.

2. Attendance to the program satisfied my expectations.

3. Program made me familiar with the university atmosphere.

4. Program influenced my ideas on choosing my profession.

5 . I could make use of all facilities of the university.

6. Professors conducted the classes interactively.

7. Professors made the course contents interesting.

8. The materials used in the class aroused my interest for the course.

9. Professors were open to informing out of the class.

10. Professors made me gain new experiences in the field.

11. The expressions of the professors were clear.

12. Seminars helped me know the professions closely.

13. I believe I benefitted from the program effectively.

14. I am thinking of continuing the friendships I gained at the program.

Table 2. Open-ended Questions used in the interview

1. Was there any relation between the content of the program and university entrance exam?

2. Did the program motivate you?

3. Was there any significant experience that you want to mention at the program?

4. What were the courses and activities you liked most at the camp? Why, write the reasons.

5. What were the courses and activities you liked least at the camp? Why, write the reasons.

6. What did you think about seminars and trips?

7. What do you suggest us when organizing a summer camp again?

8. What were your experiences that you found interesting at the camp?

Table 3. Schedule $1^{\text {st }}$ week

\begin{tabular}{|c|c|c|c|c|c|c|c|}
\hline Time & Monday & Tuesday & Wednesday & Thursday & Friday & Saturday & Sunday \\
\hline $9.00-10.00$ & Breakfast & Breakfast & Breakfast & Breakfast & Breakfast & Breakfast & Breakfast \\
\hline $\begin{array}{c}10.00-12.00 \\
\text { (Math-Natural } \\
\text { Sciences } \\
\text { Courses) } \\
\end{array}$ & $\begin{array}{l}\text { Molecular } \\
\text { Biology and } \\
\text { Genetics }\end{array}$ & $\begin{array}{l}\text { Solid } \\
\text { Works }\end{array}$ & $\begin{array}{l}\text { Molecular Biology } \\
\text { and Genetics }\end{array}$ & $\begin{array}{c}\text { Brain QEEG and } \\
\text { Biological Feedback }\end{array}$ & $\begin{array}{l}\text { Nano } \\
\text { Materials X- } \\
\text { ray Analysis }\end{array}$ & \multirow{2}{*}{$\begin{array}{c}\text { Social } \\
\text { Facilities- } \\
\text { Sports and } \\
\text { Brain } \\
\text { Teasers }\end{array}$} & \multirow{2}{*}{$\begin{array}{l}\text { Istanbul } \\
\text { Cultural } \\
\text { Tour }\end{array}$} \\
\hline $\begin{array}{l}\text { 10.00-12.00 } \\
\text { (Social } \\
\text { Sciences } \\
\text { Courses) }\end{array}$ & $\begin{array}{l}\text { Forensic } \\
\text { Psychology }\end{array}$ & $\begin{array}{l}\text { The Art of } \\
\text { Creative } \\
\text { Thinking }\end{array}$ & $\begin{array}{l}\text { International } \\
\text { Relations: Turkey- } \\
\text { European Union }\end{array}$ & $\begin{array}{l}\text { International } \\
\text { Relations: Turkey- } \\
\text { European Union }\end{array}$ & $\begin{array}{l}\text { Forensic } \\
\text { Psychology }\end{array}$ & & \\
\hline $12.00-13.00$ & Lunch & Lunch & Lunch & Lunch & Lunch & Lunch & Lunch \\
\hline $13.00-14.00$ & Free Time & Free Time & Free Time & Free Time & Free Time & \multirow{3}{*}{$\begin{array}{c}\text { Social } \\
\text { Facilities- } \\
\text { Sports and } \\
\text { Brain } \\
\text { Teasers }\end{array}$} & \multirow{3}{*}{$\begin{array}{c}\text { Istanbul } \\
\text { Cultural } \\
\text { Tour }\end{array}$} \\
\hline $14.00-16.00$ & Drama & $\begin{array}{c}\text { Self- } \\
\text { Knowledge } \\
\text { Seminar } \\
\end{array}$ & $\begin{array}{l}\text { Photography } \\
\text { Seminar }\end{array}$ & $\begin{array}{c}\text { Business and } \\
\text { Innovation Seminar }\end{array}$ & Drama & & \\
\hline \multirow[t]{2}{*}{$16.30-18.00$} & Orientation & Gastronomy & Dance & Yoga & Dance & & \\
\hline & & Florya Trip & & $\begin{array}{l}\text { Meeting with } \\
\text { International } \\
\text { Students }\end{array}$ & $\begin{array}{l}\text { Astronomy } \\
\text { (Observation) }\end{array}$ & & \\
\hline
\end{tabular}

program also introduced seven seminars on various topics and several activities (Tables 1 and 2). Students chose the courses before starting to the camp. They had a change to choose three different courses and all students' participation to activities and seminars were compulsory. Throughout the study, the students hosted by Istanbul Aydin University's dorm for two weeks. In this period students were benefited all facilities of the dorm which had a high-quality living standard. 
Table 4. Schedule $2^{\text {nd }}$ week

\begin{tabular}{|c|c|c|c|c|c|}
\hline Time & Monday & Tuesday & Wednesday & Thursday & Friday \\
\hline $9.00-10.00$ & Breakfast & Breakfast & Breakfast & Breakfast & Breakfast \\
\hline $\begin{array}{c}\text { 10.00-12.00 (Math- } \\
\text { Natural Sciences } \\
\text { Courses) }\end{array}$ & $\begin{array}{l}\text { Molecular } \\
\text { Biology and } \\
\text { Genetics } \\
\end{array}$ & $\begin{array}{c}\text { Brain QEEG and } \\
\text { Biological } \\
\text { Feedback } \\
\end{array}$ & $\begin{array}{l}\text { Solid } \\
\text { Works }\end{array}$ & $\begin{array}{c}\text { Brain QEEG and } \\
\text { Biological Feedback }\end{array}$ & $\begin{array}{l}\text { Next Generation } \\
\text { Learning Models: } \\
\text { Web 2.0-3.0 Tools } \\
\end{array}$ \\
\hline $\begin{array}{c}10.00-12.00 \text { (Social } \\
\text { Sciences } \\
\text { Courses) }\end{array}$ & $\begin{array}{l}\text { The Art of } \\
\text { Creative } \\
\text { Thinking }\end{array}$ & $\begin{array}{l}\text { Forensic } \\
\text { Psychology }\end{array}$ & $\begin{array}{c}\text { The Art of Creative } \\
\text { Thinking }\end{array}$ & $\begin{array}{l}\text { International Relations: } \\
\text { Turkey- European Union }\end{array}$ & $\begin{array}{l}\text { Next Generation } \\
\text { Learning Models: } \\
\text { Web 2.0-3.0 Tools }\end{array}$ \\
\hline $12.00-13.00$ & Lunch & Lunch & Lunch & Lunch & Lunch \\
\hline $13.00-14.00$ & Free Time & Free Time & Free Time & Free Time & Free Time \\
\hline $14.00-16.00$ & Drama & $\begin{array}{c}\text { Economy and } \\
\text { European Relations } \\
\text { Seminar }\end{array}$ & $\begin{array}{l}\text { Future Planning } \\
\text { Seminar }\end{array}$ & $\begin{array}{c}\text { Business and Innovation } \\
\text { Seminar }\end{array}$ & Coffee Workshop \\
\hline \multirow[t]{2}{*}{$16.30-18.00$} & Orientation & Gastronomy & Dance & Yoga & Dance \\
\hline & $\begin{array}{l}\text { Meeting with } \\
\text { International } \\
\text { Students }\end{array}$ & & $\begin{array}{l}\text { Astronomy } \\
\text { (Observation) }\end{array}$ & & \\
\hline
\end{tabular}

When the program mentioned day by day;

The first day: Students were welcomed at university D Block and all students had a breakfast at university canteen with supervisors. After a short meeting with students and supervisors, some students went to the Molecular Biology and Genetics class. At the first day of the lesson, they learned about the beginning of life, cells, structure of cells and epicyte. Also cells' communication system was worked on. The other group of students took Forensic Psychology and at this lesson they study on the titles; psychological birth of human and basic concepts of Forensic Psychology. Some students could join both of the courses if they would like to. With the ending of this course they had free time till 14.00. At their free time they had a chance to wander around the campus and had coffee with their new friends. In the afternoon they took Drama Lesson and they had ice-breaker activities for meeting everyone. At the orientation part, supervisors told about whole program, university campus and facilities. They introduced themselves again and took students different departments labs, the rules that should be obeyed that labs and their mission. Between18.00-19.30 they had breakfast and by a mini bus they were taken to the dorm with four of the supervisors and they were settled to their rooms as two or three people. They were also introduced about the dorm and they were informed about using dorm facilities such as game-area, TV hall, sports center etc. At 23.00 they were informed about to go to their room and have a rest.

Second day: At 8.00 o'clock the students were taken from the dorm and brought to the university with supervisors. They had their breakfast till ten o clock. Some of them had solid works course at computer lab. They were firstly introduced Scratch instructions then solid works software, its usage and its parts and they only experienced some simple shapes drawings such as circle and square with the directions of the lecturer. Then other group attained the course "The art of creative thinking" in that they discussed the meaning of creativity and what is creative and why based on the examples. They also watched stopmotion videos on creative works and by learning the criteria of creative thinking they evaluated the works according to these criteria. They also studied on "how to draw from a point" as an activity. In the afternoon all students had a seminar on knowing about themselves and learning about self. At the seminar they questioned their likes and dislikes, do they know their interests and talents, what are the emotions that they feel in a day most etc. at seminar saloon of the university. At this scope ice breaker called "stacked name" applied, development stages of human, life window of Johari, being a good team handled and discussed by using creative drama and games. Then all of them went to Gastronomy lab and the lecturer told them about gastronomy and its origin. Importance of healthy eating and they cooked two different Turkish meals together and ate it. Discussed why one of the meal healthy but the other not by using the criteria. 18.30 all students were taken to Florya a coastal region of Istanbul near to the university by minibuses. They are given three free hours for sightseeing or dinking something then everybody was ready at 21.30 to go to dorm. After this hour they were given free time till 23.00 and they were visited at their room at 23.00. They were checked whether they were at their room or not.

Third day: Students were brought from the dorm 8.00 and they were taken to the university by buses. They had their breakfast till ten o clock and some of them went to Molecular Biology and Genetics labs. They observed different cells on the microscopes and designed a cell model. They also worked on male reproductive system, female reproductive system and nucleus. Then they observed testicular, ovary, live human sperm and bull sperm on microscope. The class was carried by hands on experiments. At International Relations: Turkey- European Union course they worked on the basic concepts such as "international relation", "union" and the actors of international relations such as governments, GNO's, international firms etc. They also worked on the types of international 
relations. The institutions which regulate international relations and United Nations. They also learned about these sub-foundations such as UNICEF, UNESCO and UNDP. They watched mini videos on these institutions and foundations and they learned about their functions. They prepared questions at the end of the course and they tried to answer these questions together. They had free time till 14.00. And they were taken to the seminar hall for the photography seminar. The lecturer told students about the techniques of right photograph taking and the importance of the light in photograph taking. They studied on some object for taking the rightest aspect. At 16.30 all the students were ready at the sports hall and they had their first dance course. They were introduced modern dance types and they were taught the basic steps of salsa. At 18.00 till 19.30 it was time for dinner and they had their dinner at university canteen. After having their meal, they were taken to the dorm by bus at 20.00. Till 23.00 it was free time of the students at dorm. Some of them preferred to spend their time for playing games at the game area, some of them preferred to go out for drinking coffee around the dorm. At 23.00 they were visited and checked at their room.

Fourth day: Students were taken from the dorm by school bus at 8.00 and they were taken to the university. They had their breakfast till ten o clock and they took Brain QEEG and Biological Feedback course. At the course they introduced and they mentioned about their dreams. They questioned whether they have mindsets about reaching their aims or not. Then they discussed how the brain think and what the effective usage of brain. At International Relations: Turkey and European Union; they worked on "why European Union emerges?, what is integration and its processes, economic integration and economic and the other alliances such as Rome, Maastricht and Lisbon treaties". At 14.00 o'clock they had Business and Innovation Seminar from the manager of Aras Cargo a prestigious company in Turkey. Firstly, some applications were handled to make students know themselves more; some tests about their personality types administered. They learned how to use all these information and studied the concept of effective communication and emotional IQ. At 16.30 they had yoga course at sports hall. They learned the origin and the philosophy of yoga and fundamental movements by doing them. After their dinner at around 19.30 the students are introduced to fifteen international students at campus. They had coffee together and international students mentioned about themselves, their branch, country, the reason they have education in Turkey and etc. At 21.00 they were taken to the dorm and had free time till $23.00 \mathrm{o}^{\prime}$ clock.

Fifth day: The students were ready at 8.00 o'clock at the dorm and they were taken to the university with the buses. After they had breakfast at university canteen, they had Nano Materials X-ray Analysis seminar. For this seminar computer lab is used and we uploaded a special computer program on the main computer. Because we connected to METU's electron-microscope which shows the materials' all tissues. Students were told the working principles of electron-microscope and shown many pictures, tried to guess which pictures belong to what. They also learned why $x$ ray is used. At 10.15 o'clock they took Forensic Psychology and they discussed the criminals, crime types, psychopathology and forensic psychology. They watched some parts of films that students can apply their knowledge. They had their lunch at 14.00 they had drama and dance. At drama lessons they played games on being a good team and at dance they practice salsa's more difficult steps. After dinner all students were taken to the Observatory and they got information about planets. They observed star clusters with telescope and raised awareness about how earth moves. They learned that the sky doesn't settle in the same way. They drew the picture of star clusters and created new names for all clusters. At 02.00 o' clock they were taken to the dorm.

Sixth and seventh day: On Saturday they had their breakfast and they were taken to the university. After they were taken to leisure center of university in Tepekent. They could swim and do sports there also they could play some games such as gammon or go. They had lunch and dinner in Tepekent. At 21.00 students were taken to the dorm. On Sunday they were firstly taken to Koc museum which includes many parts from technology to transportation. They saw the oldest computers, cars, clocks and etc. They also got the train at the museum. After this visiting they were taken to the Florya coast and had their dinner. At 21.00 they were taken to the dorm and till 23.00 they were free.

Eighth day: At 8.00 o'clock the students were taken from the dorm and brought to the university. They had their breakfast till ten o clock. After having their breakfast, they firstly had Molecular Biology and Genetics course and they studied on genetics. They learned about chromosomes, DNAs, genetics / Mendel genetics and mutations. At the art of creative thinking course, they studied on creativity in science, watched videos of non-existent ships and learned an animation program called "stop motion" for starting to their project. They chose a social topic they wanted to study such as "saving animals", "preventing women from violence" etc. and they wrote a scenario by the guiding of the lecturer. They evaluated their scenarios after writing it according to the creativity criteria. They had lunch and free time till 14.00 o'clock. Some of the students spent their time at sports hall, some of them spent at computer lab, some of them had coffee with his/her friends etc. At 14.00 they took Drama and at 16.30 they visited all the departments of university as a part of orientation program. Till 21.00 they had a meeting with our international students and they taught their games to each other unique to their culture. At 21.00 they were taken to dorm and it was free time of them till 23.00. They generally preferred to use game area with their friends and with their supervisors. 
Ninth day: The students were taken to the university at 08.30 and they had their breakfast till 10.00 at university canteen with supervisors. After that they had Brain QEEG and Biological Feedback that they studied on effective study techniques and examined the latest Brain researches. At Forensic Psychology course they studied on domestic murders and affective disorders. After this class they had Economy and International Relations: Turkey- European Union. Why and what kind of economical relations Turkey have with European countries and which institutions support these relations discussed. It aimed to students learn about Turkey's economic situation and its effects on Turkey's international relations with Europe. From 16.30-18.00 they had their dinner and made a special desert in Gastronomy lab. After this time till 21.00 it was free time of students at university campus.

Tenth day: After students taken to university campus and having their breakfast they had Solid works course at computer lab. They worked on creating a solid model (AutoCAD) and drew transportation means whatever they wanted to with the help of the lecturer such as plane, car or etc. At the creative thinking art course students studied on their documentary project by using stop motion and they watched all the documentaries and they evaluated all the products according to the criteria of creativity. At 14.00 they had "Future Planning Seminar" that they were given information about the occupations their requirements, trend occupations in the next 20 years and its reasons. The students are applied learning style inventory of KOLB and the results were shared with them. Students could see the appropriate occupation for themselves according to KOLB inventory. After 16.00 they had dance course and they practiced the movements they learned with music. And they were taken to the observatory and they got information about the planets and their characteristics. They observed planets such as Venus, Saturn, Jupiter and its satellites and the moon. Then they were taken to the dorm and had free time till 23.00 o'clock.

Eleventh day: After student were taken to the dorm and having their breakfast, they had Brain QEEG and Biological Feedback course. At this course they examined the brain tools used in brain researches. They studied on Biofeedback and learned about equipments and their working system. At International Relations: TurkeyEuropean Union course they worked on crisis that European Union experienced in current years, Greece Debt Crisis and 2015 Referendum, Grexit, TTIP process, Brexit and the next developments were handled and discussed. The future of the European Union and the future of Turkey-EU relations were the main topic that the group worked on. At 14.00 o'clock all the students had Business and Innovation seminar and they learned the importance of creating, writing, applying and managing projects from a project expert. Then they had yoga and after having dinner they were taken to the dorm at 19.30 .

Twelfth day: After having their breakfast all students had Next Generation Learning Models: Web 2.0-3.0 Tools seminar and they learned the importance of tools and they learned to use tools such as Padlet, Kahoot, Mind Mup and Prezi as an alternative presentation tool. They learned to create educational gaming software with Web 2.0-3.0 Tools and designed their logos for our summer camp with vector graphics programs. of Web 2.0-3.0 Tools After having their lunch and free time they had a coffee-making workshop at our campus Starbucks. They learned about different kinds of coffees, their blasting types and their making. They watched a coffee-making show and tasted different coffees. At 16.30 to 18.00 they had dance course and at 18.00 the certification ceremony took place. They got their certificates and filled in the evaluation forms. Then all the group had a dinner together. Some students' families came and took some of them. Others were taken from dorm on Saturday with the help of the supervisors.

\section{RESULTS}

Table 5 presents the frequencies of the students' responses to 14 rating scales on the semi-structured interview.

Table 5. Frequencies of the students' responses in the interview

\begin{tabular}{|c|c|c|c|c|c|}
\hline \multirow{2}{*}{$\begin{array}{l}\text { Questions } \\
\text { (1: Strongly disagree, 5: Strongly agree) }\end{array}$} & \multicolumn{5}{|c|}{ Frequency } \\
\hline & 1 & 2 & 3 & 4 & 5 \\
\hline The content of the program cohered with its introduction. & 1 & 0 & 4 & 17 & 17 \\
\hline Attendance to the program satisfied my expectations. & 0 & 1 & 6 & 9 & 23 \\
\hline Program made me familiar with the university atmosphere. & 1 & 0 & 7 & 11 & 20 \\
\hline Program influenced my ideas on choice of profession. & 0 & 4 & 9 & 9 & 17 \\
\hline I could make use of all facilities of the university. & 0 & 4 & 7 & 9 & 19 \\
\hline Professors conducted the classes interactively. & 0 & 0 & 5 & 11 & 23 \\
\hline Professors made the course contents interesting. & 0 & 0 & 4 & 17 & 18 \\
\hline The materials used in the class aroused my interest for the course. & 0 & 4 & 6 & 12 & 17 \\
\hline Professors were open to informing out of the class. & 0 & 0 & 1 & 7 & 31 \\
\hline Professors made me gain new experiences in the field. & 0 & 0 & 2 & 15 & 22 \\
\hline The expressions of the professors were clear. & 0 & 0 & 3 & 11 & 25 \\
\hline Seminars helped me know the professions closely. & 0 & 3 & 9 & 14 & 13 \\
\hline I believe I benefitted from the program effectively. & 0 & 0 & 4 & 16 & 19 \\
\hline I am thinking of continuing the friendships I gained at the program. & 0 & 3 & 5 & 10 & 21 \\
\hline
\end{tabular}


Table 6. The Relationship Between Program and University Entrance Exam

\begin{tabular}{llcc}
\hline Theme & Code & Frequency & Percentage \\
\hline & Program was beneficial & 19 & 39.6 \\
\cline { 2 - 4 } The Relationship & Program was relaxing & 8 & 16.7 \\
\cline { 2 - 4 } $\begin{array}{l}\text { between Program } \\
\text { and University }\end{array}$ & Program was motivating & 5 & 10.4 \\
\cline { 2 - 4 } Entrance Exam & Program was interesting & 5 & 10.4 \\
\cline { 2 - 4 } & Program was enjoyable & 4 & 8.3 \\
\cline { 2 - 4 } & The student wasn't interested in studying for the university exam & 3 & 6.3 \\
\cline { 2 - 4 } & Program hindered getting prepared for the exam & 1 & 2.1 \\
\hline
\end{tabular}

Since summer school program aimed at introducing new courses to the students with enriched content, university preparatory courses (There are special courses organized for preparing the high school students to the university entrance exam) were not included. When the students were asked their ideas about this situation, 39.6\% of the students stated that this was beneficial and $16.7 \%$ of the students stated that this was relaxing for them, as can be seen in Table 6 above.

S4: "I did not take any course related to the subjects of university entrance exam and my intention was not about it. I came here to learn about the professions and decide which major I would choose to study on. This program helped me a lot. It shaped my ideas on this issue. Especially, I got more favorable result than I wanted."

S5: "I had new ideas and choices on choosing my career so I found it beneficial."

S7: "In my opinion the camp being not to designed for university entrance exam was useful because the courses we attained were the usual university courses. This ensured us to understand the university life better."

S19: "I think this camp is quite useful in terms of people's comfort. If I evaluate the situation from my point of view even the camp did not make a direct impact on my preparation for the university entrance exam, it guided me indirectly question the exam and get to know different professions. If the camp was aimed at the university entrance exam, individuals who felt under pressure throughout the entire program would not benefit from these opportunities."

S15: "I think the focus of the program wasn't on the basic lessons such as physics, chemistry and mathematics but rather it focused on the courses such as International Relations, Psychology and Brain or social life such as dance lessons, yoga etc. made the camp different from other summer camps. Although I personally will not enter the university exam, I think that dance and yoga classes relieved my friends who will enter the exam in the following years. I think the camp was quite successful in this regard.

S13: "As a student who will enter the university exam, learning about the details of university exam could be beneficial but we weren't informed about anything related to the university exam. So I tried to make inferences about university exam from some speeches or seminars and I tried to associate all these information with the university entrance exam."

S16: "I think if the students participating in this program were generally considered to be candidates for the exam, a small informational seminar on the university exam could be given. However, when I looked at it from the point of view of the students, this lack could be seen as an advantage. Because \% 80 of students participated in this program in order to get rid of the exam stress and take a final breath before the busy year. Finally, I would like to make a proposal. A presentation can be made by the guidance service about what students should look for when choosing a career. Afterwards, a discussion can be organized between the students by the staff."

S28: "Yes, we were introduced about some professions on some fields but in that kind of a situation our tendency to that field is only strengthened in the direction of our needs. Generally, there is little mention of the future situation of that profession and the importance of the sector. At the same time, there is little mention of the rush-hour of the selected department of that profession during the university period, the future prospect of the profession, the opportunity for the profession to work in the broader field and the profession openness to producing ideas and projects. I listen to these kinds of topics with care and attention." 
EURASIA J Math Sci and Tech Ed

Table 7. Academic Motivation

\begin{tabular}{lccc}
\hline Theme & Code & Frequency & Percentage \\
\hline \multirow{2}{*}{ Academic } & Yes & 34 & 87.2 \\
\cline { 2 - 4 } Motivation & Partially & 4 & 10.3 \\
\cline { 2 - 4 } & No & 1 & 2.6 \\
\hline
\end{tabular}

Table 8. Significant Experiences

\begin{tabular}{llcc}
\hline Theme & Code & Frequency & Percentage \\
\hline & Learned about different professions & 7 & 19.4 \\
\cline { 2 - 4 } & Socialization & 6 & 16.7 \\
\cline { 2 - 4 } Significant & Awareness & 6 & 16.7 \\
\cline { 2 - 4 } & None & 6 & 16.7 \\
\cline { 2 - 4 } & Communications with the program staff & 6 & 16.7 \\
\cline { 2 - 4 } & Used high quality materials in course & 1 & 2.1 \\
\cline { 2 - 4 } & Taken courses lectured by Professors & 1 & 2.8 \\
\cline { 2 - 4 } & &
\end{tabular}

As it is shown in Table 7, 87.2\% of the students stated that the summer school program motivated them academically. They said:

S18: "Yes, especially it reminded me not to underestimate myself and procrastinate."

S21: "Listening to the experts and professors in the field enabled us to have a lot of knowledge on that field. I can tell you that I decided what kind of academic career I will have in the future."

S28: "Especially because the program focusing on motivating courses, I was informed about the choice of profession as well as my self-confidence increased. Choosing a career is, of course, a critical choice but this is not a death or catastrophe, and it is possible to grasp them from the experiences of the academicians and from their speeches."

S35: "Yes. I was excited for the professions that I have never heard before and I thought I should study English more."

S20: "This program in general helped me to choose my profession. I was happy to learn what I did not know, and this thing motivated me. But I do not know if the program motivated me "academically".

S22: "Partially. After the program, I began to think that I needed to be versatile."

During the summer school program, students told about the significant experiences they gained and $19.4 \%$ of the students stated that they learned about different professions; $16.7 \%$ of them named socialization, awareness and their communications with the program staff as crucial experiences meanwhile \%16.7 reported that they had no outstanding experience at the summer school program.

S7: "I learned how to use my brain actively and how to plan. I also understood that I could handle without my family."

S19: "Maybe I will not do the activities we did in drama course again in my life. However, I realized that my creativity has changed. Program made me realize this... I learned and added one more thing to my do list and my life."

S24: "I socialized with everyone for the first time and had fun."

S36: "It made me learn the things that I was curious about but could not learn due to the lack of correct resources. For example, Solidworks, software, material engineering examining substances with electron microscope..."

S20: "It is an interesting experiment to study at the laboratory of the genetic engineering and to spend time at university leisure center. This made me very happy. But there is not much I can explain."

S22: "I regret that I did not go to the drama course when I was a child. I have made very nice friendships." 
Table 9. The Courses and the Activities Liked Most

\begin{tabular}{|c|c|c|c|}
\hline Theme & Code & Frequency & Percentage \\
\hline \multirow{11}{*}{$\begin{array}{l}\text { The Courses and } \\
\text { the Activities Liked } \\
\text { Most }\end{array}$} & Brain QEEG and Biological Feedback & 17 & 27.0 \\
\hline & International Relations: Turkey European Union & 11 & 17.5 \\
\hline & Forensic Psychology & 8 & 12.7 \\
\hline & Molecular Biology and Genetics & 8 & 12.7 \\
\hline & Dance & 5 & 7.9 \\
\hline & Drama & 4 & 6.3 \\
\hline & Nano Materials and X-ray Analysis & 4 & 6.3 \\
\hline & Solid Works & 3 & 4.8 \\
\hline & Yoga & 1 & 1.6 \\
\hline & STEM & 1 & 1.6 \\
\hline & Astronomy & 1 & 1.6 \\
\hline \multicolumn{4}{|l|}{ Table 9.1. Reasons } \\
\hline Theme & Code & Frequency & Percentage \\
\hline \multirow{6}{*}{ Reasons } & Interesting & 15 & 30.6 \\
\hline & Given by specialists in the field & 11 & 22.4 \\
\hline & Curiosity & 9 & 18.4 \\
\hline & Creating awareness & 8 & 16.3 \\
\hline & The attitudes of the professors & 3 & 6.1 \\
\hline & Enjoyable & 3 & 6.1 \\
\hline
\end{tabular}

Table 10. The Courses and Activities Liked Least

\begin{tabular}{|c|c|c|c|}
\hline Theme & Code & Frequency & Percentage \\
\hline \multirow{8}{*}{$\begin{array}{l}\text { The Courses and } \\
\text { Activities Liked } \\
\text { Least }\end{array}$} & Nonexistent & 14 & 35.6 \\
\hline & Solid Works & 8 & 20.5 \\
\hline & The Art of Creative Thinking & 7 & 17.9 \\
\hline & Yoga & 4 & 10.3 \\
\hline & International Relations: Turkey European Union & 2 & 5.1 \\
\hline & Drama & 2 & 5.1 \\
\hline & Brain QEEG and Biological Feedback & 1 & 2.6 \\
\hline & Molecular Biology and Genetics & 1 & 2.6 \\
\hline \multicolumn{4}{|c|}{ Table 10.1. Reasons } \\
\hline Theme & Code & Frequency & Percentage \\
\hline \multirow{4}{*}{ Reasons } & Boring & 10 & 38,5 \\
\hline & Not interested & 10 & 38,5 \\
\hline & Not meeting the expectance & 4 & 15,4 \\
\hline & The attitudes of the professors & 2 & 7,7 \\
\hline
\end{tabular}

S28: "Especially the dormitory environment was nice. There were neither very comfortable nor very strict rules in the residence. I also liked to study with microscopes in genetics course. At the same time we reached the electron microscope images via METU. To see the smallest details of many items reminded us of how big we are in reality; but the observation of the sky with telescope made us feel how unimportant we are in the universe. The camp was pleasant in general."

S29: "I could not say that I had an interesting experience, but I enjoyed the seminars and lessons, which was a good experience for me.".

In line with the enriched education program, the courses from different fields were included to make the students realize their own interests and skills. In this scope, the courses and the activities that the students liked most are presented in Table 9, the reasons are given in Table 9.1, the courses and the activities they liked least are shown in Table 10 and the reasons are presented in Table 10.1.

The courses that the students liked most were Brain QEEG and Biological Feedback (27\%), International Relations: Turkey European Union (17.5\%), Forensic Psychology (12.7\%), Molecular Biology and Genetics (12.7\%). The reasons behind the interest for these courses were that the courses were interesting for them $(30.6 \%)$, they were given by specialists in the field $(22.4 \%)$, the students were curious about the course $(18.4 \%)$, the course created 
awareness $(16.3 \%)$, the attitudes of the professors towards the students were nice $(6.1 \%)$ and the course was enjoyable $(6.1 \%)$.

S9: "Dance, Drama, Brain QEEG and Biological Feedback courses the one I liked most. Because the lecturers of these courses are really professional and these courses topics attracted me."

S14: "I liked International Relations: Turkey European Union course because the topics matched with my interest also the lecturer is a real professional in the field also at pedagogy. He was successful in attracting us."

S16: "Brain QEEG and Biological Feedback and the Forensic Psychology courses my favorite ones. Both the attitudes of professors were nice and the topics were interesting."

S18: "Forensic Psychology. I realized at the course that the field is constantly in action. That's why I like it very much."

S22: "Drama courses were the most beneficial ones for me. Also, the content of International Relations course topics were interesting because we neither we receive any courses related to the recent history nor reach reliable sources so far."

S15: "I liked International Relations and European Union and dance activities most. International Relations course made me realize that I am not an appropriate person for math-natural sciences and I have a tendency for social sciences. Dance course... I do not know, I just liked it. I could say that I discovered myself. Dance teachers taught us as many dances and techniques as they could in 2-week time. I am leaving the camp having learned how to dance Salsa with a girl without hesitation."

S19: "Molecular Biology and Genetics. Both the expression of the professor and the sincerity between us were very nice. I have met the smartest person I have ever seen and the talks he gave to orient us to science were quite enjoyable. Also, I liked the brain-related course, it was good for us in terms of time management and self-knowledge. The sincerity and smartness of the professor had a big influence on this."

At the end of the enriched summer school program, the students were asked about the courses they liked least. $35.6 \%$ of the students stated that there was no course that they did not like at all. Some of the students listed the courses that they liked least: Solid Works activity (20.5\%), The Art of Creative Thinking (17.9\%), Yoga (10.3\%). When the students were asked about the reasons why they did not like those courses, $38.5 \%$ of them stated that the course was boring, $38.5 \%$ of them stated that they were not interested in the course, $15.4 \%$ of them said that their expectations was not met and $7.7 \%$ of them told that they did not like the course because of professors' attitudes.

S20: "In fact, there wasn't any course that I did not like. Of course, I am very bored in some lessons, but there is no lesson I can say that I do not like this course at all."

S29: "There was not any class that I did not like because when I was choosing the courses, I decided them according to my interests."

S1: "I found Solidworks less than I expected. Even though the time was limited, more could be done with better planning. The lecturer of the course also seen as reluctant."

S19: "Creative Thinking Art. The professor certainly did not have a sympathetic impression on me and it was not at all motivating to watch the stop motion videos for 45 minutes."

S34: "Drama and Brain QEEG and Biological Feedback. The lecturer we had in Drama course was very good at her job but the course was not match my interest. I would prefer not having taken this course although it helped me learn the other students' names. We took Brain QEEG and Biological Feedback course three times. The first time was very interesting for me because we studied and learned about brain parts and functions but the following times were focused on students coaching in which the he gave lectures about effective study skills so I could learn only a few things about brain. 
Table 11. Seminars and Trips

\begin{tabular}{lccc}
\hline Theme & Code & Frequency & Percentage \\
\hline & Enjoyable and interesting & 30 & 52.6 \\
\cline { 2 - 4 } Seminars and Trips & Boring & 12 & 21.1 \\
\cline { 2 - 4 } & Suggestion about practice & 8 & 14.0 \\
\cline { 2 - 4 } & Informative about professions & 4 & 7.0 \\
\cline { 2 - 4 } & Socializer atmosphere & 3 & 5.3 \\
\hline
\end{tabular}

Table 12. Suggestions

\begin{tabular}{llcc}
\hline Theme & Code & Frequency & Percentage \\
\hline \multirow{4}{*}{ Suggestions } & About practices & 10 & 24.4 \\
\cline { 2 - 4 } & Free time & 8 & 19.5 \\
\cline { 2 - 4 } & Enhancing course diversity & 6 & 14.6 \\
\cline { 2 - 4 } & Self-regulation & 5 & 12.2 \\
\cline { 2 - 4 } & About timeline of the program & 5 & 12.2 \\
\cline { 2 - 4 } & Meals & 4 & 9.8 \\
\cline { 2 - 4 } & Increasing the class hours & 3 & 7.3 \\
\hline
\end{tabular}

Related to seminars and trips organized within the summer school program, $52.6 \%$ of the students said that they were enjoyable and interesting, $21.1 \%$ of the students stated that they were boring, $14 \%$ of the students made some suggestions about them and $5.3 \%$ of the students said that these organizations socialized them.

S18: "They were well-organized and it was very nice that they were optional. They also appealed to my keens."

S15: I love it all, yoga was a bit of a challenge, but it was still pretty good. I already explained why I like dance classes at prior question. The trip to Tepekent-leisure center of the university-was also a very nice experiment. I had good time with my friends there by swimming, playing and wandering around."

S35: "Most of the seminars were really fun and informative at the same time. But in some of them I was bored since I am not interested in the subject. I do not know about Yoga and Dance courses because I took Software course. I have attended Yoga only once, it was good although I got tired a bit..."

S39: "Seminar subject could have been more interesting. I can say that dancing was a nice experience for us. Yoga should be done in quiet, not crowded and, most importantly, in an airy environment in the morning hours. Also, I do not believe that yoga suited the students' fancy."

When the students were asked to make recommendations related to the content of the program $24.4 \%$ of the students focused on the practices, $19.5 \%$ of them talked about free time, $14.6 \%$ of them focused on the course diversity, $12.2 \%$ of them told about self-regulation, $12.2 \%$ of them preferred to talk about timeline of the program, $9.8 \%$ of them focused on meals and $7.3 \%$ of them told about increasing the class hours.

\section{S6: "Seminars on Business Life and Innovation could be more detailed."}

S36: "Two hours a little longer for a lesson. It was very difficult to give attention to the same thing for such a long time, even if it was a subject that attracts much interest. Maybe the class hours can be divided into two or three parts."

S8: "We should have been able to wander around the camp not in groups but individually. If we had tried to find our classes on our own, it would have been a better experience for us. It would have been better if classroom and time were specified and everyone went to class alone."

S29: "I have not had such experiences in high school and secondary school. It was just mentioned in the books, but it was neither told livelily nor good sides of the professions were mentioned. Maybe it was bad for some people, but we broadened our viewpoints; we met different people from different places, we saw different environments and taboos of people in choice of profession."

S39: "My suggestion is to increase the number of people coming to the program and let the students go around themselves on campus as if they were real university students. It is boring to attend the classes and to go around the campus as a group accompanied by program staff. Also, course choice 
Table 13. Experiences in the Program

\begin{tabular}{lccc}
\hline Theme & Code & Frequency & Percentage \\
\hline \multirow{3}{*}{$\begin{array}{l}\text { Experiences in the } \\
\text { Program }\end{array}$} & Socialization & 24 & 45.3 \\
\cline { 2 - 4 } & Awareness & 10 & 18.9 \\
\cline { 2 - 4 } & University life & 10 & 18.9 \\
\cline { 2 - 4 } & Learning about the professions & 9 & 17.0 \\
\hline
\end{tabular}

should not be like this, we need to be able to arrange our own schedule. Yoga, dance and drama courses must be elective."

\section{S13: "The meals could me more different and delicious."}

At the end of enriched summer program, students stated that they gained experiences most in subjects such as socialization $(45.3 \%)$, awareness $(18.9 \%)$, university life $(18.9 \%)$, learning about the professions $(17 \%)$.

S11: I was at a university environment for the first time in my life which was even a nice experiment for me. I also had the chance to speak with people who specialize in certain topics."

S13: "I realized that I could make close friends and my questioning and socialization skills improved."

S7: "I grasped at the camp that the success in life is up to our social life as well as our academical skills."

S6: "I experienced and understood the university life. I also learned to adapt new environments."

S30: "I have not had any experiences in high school and secondary school before. Of course, the books referred to the topics, but we had not been given these pleasurable and interesting aspects of the professions. These topics were particularly emphasized here. This may be bad for some people, but to learn about different people's thoughts from different places and their taboos about the occupational choices has broadened our point of view."

S15: "In contrast to what I believe, I realized that I am not appropriate for math-natural sciences and I have a tendency for social sciences. Also, I had many close friends from different cities and schools during the camp. I gained more experience than this but this is all I remember."

S22: "Friendships were very nice... The atmosphere you prepared for us was priceless. The ones from prestigious schools did not say "Where am I?" and the others from other cities became part of this qualified atmosphere. I happened to learn the tolerance level in such a colorful program. It was really professional and the interest in seminars and courses was amazing. Congratulations...Psychology, dance, photography and drama were especially stimulating."

\section{DISCUSSION AND CONCLUSION}

In the summer camp organized for high school students at Istanbul Aydin University, an education program including nine courses, seven seminars and various activities was presented. The analysis of the interview data revealed different codes, which are presented with examples and discussed below.

\section{University}

Tekbiyik et al. (2013) suggests that the program in their study could have been more effective in a university environment. Also when the literature is analyzed; it is possible to see that nearly all camps especially the ones with career oriented organized at universities and aimed to research their effects on student's career choices as well. Ayar et all (2013) study a two-week robotics summer camp for high school students carried out at a university, Downey and his colleagues (2016) IT majors through an annual high school IT camp also one of these examples (Downey et all., 2016). Ciloglugil et al (2016) can be another example designing an engineering outreach project that aims to promote insight on high school students towards computer hardware and its mathematical background which also carried out at a university. These examples number can be increased but practitioner and researchers generally prefer university environment for organizing their career-oriented camps. The labs, campus facilities and the easiness of reaching professionals could be the main reasons why universities are the forefront of these kind of studies. Related to the program organized at a university in the present study, the students responded positively. Most of them $(79.5 \%)$ stated that they could have the chance of learning about university life. S20 said: "The summer 
camp at Istanbul Aydin University was a good opportunity for me. It helped me learn different professions and enjoy myself for two weeks. I thank you everyone taking part in this organization and giving us this chance." S7 said: "I had prejudiced Istanbul Aydin University... I thank the professor at this university as they told us the beauties of university and shared their experiences." S39 said: "My viewpoint about charity board universities has changed." S28 said: "...Long live Istanbul Aydin University." S20 said: "...I learned the university life... I enjoyed a lot in this two-week time and also had information of good quality in Istanbul Aydin University." Even some students emphasized the program was so intense and they felt tired, many students underlined that they learned about university life, new fields, how to communicate with lecturers and all these led them to new decisions or think on their career choice again.

\section{Social Relation}

According to the qualitative analysis of the data, the most mentioned issue is that the students could improve their social skills. Many researchers have contended that positive peer relationships are one of the best predictors of later adjustment. Also, rejection led to higher adolescent internalizing problems. Internalizing problems are related to a host of serious adjustment outcomes thereby leading to more interpersonal problems and a cycle of rejection (Buskirk-Cohena, 2015). If we handle for being successful in life, adjustment and adaptation is essential, making students experienced these kinds of emotions and developing these skills, creating an environment for them to use and develop these skills gain importance. It is very usual that many studies reported the summer camps help students to improve social skills parallel to our findings (Marulcu et al. 2014; Konur et al. 2011; Smith et al. 2010; Tekbiyik et al. 2013). Students (79.4\%) stated that they would like to continue the friendships they gained throughout the program. They also mentioned that they could communicate easily with each other and the program staff and they could express themselves easily. S7 said "All activities and seminars guided us to socialize and recognize each other." S8 said: "I understand that success in life is related to social life as much as it is to academic success.", S20: "I had new and beautiful friends. Each person is different world. This is the most important experience of mine. Also, I was able to meet Mustafa Aydin (The Chairman of the University Board of Trustees), which was also important.", S19 said: "...especially the program staff became our friends just like other peers coming for the camp." But of course there were some students who thought S18: There was very limited activities in the evenings so being at the dorm obliged me spiritually; S29: Activities could be more varied and instead of putting a single event, two different events can be put simultaneously.

Bean, Kelsey and Forneris (2016) stated in their study that participation in a leisure activity, and in particular residential summer camp, provided youth with unique developmental experiences that they perceived supported their basic psychological needs. The participants reported indicating that they 'strongly agreed' camp was a context that supported the needs of autonomy, competence, and relatedness. Moreover, presented participants identity experiences, initiative experiences, basic skills, interpersonal relationships.

\section{Professions}

One of the aims of enriched summer school program is to make students familiar with different professions. The seminars $(69.2 \%)$ and courses $(66.7 \%)$ organized in the program were found to be influential in students' choice of profession parallel to the literature (Foster \& Shiel-Rolle 2011; Knox et al. 2003; Helm, Parker \& Russel 1999; Markowitz 2004; Vekli 2013; Martinez \& Hibbs 2003). Downey and his colleagues examined the results of a camp organized by one university and a global IT firm to help increase IT majors through an annual high school IT camp focused on invigorating interest in technology careers. The camp was four-day long and the data collected from five camps between 2010-2014. They found that the camp significantly increased their career awareness and positive attitudes toward an IT career. Although the camp objectives didn't be met, the IT camps played a crucial role in boosting interest in IT as a career and enhancing perceptions and beliefs of IT (Downey et al, 2016).

Here are some comments from the students: "This program is quite good in that it is prepared for Grade 9 and 10. We have 2 or 3 years ahead. It is good for us to know about the professions now." (S35), "The profession scale for us to choose has expanded and we learned about university life, which all important and beneficial for us." (S5).

\section{Awareness}

Qualitative analysis of the data showed that the students dwelled on awareness. This result was also yielded by previous studies, which also underlines that activities like summer camp has an encouraging effect on awareness (Allen et al. 2011; Bhattacharyya, Mead, \& Nathaniel 2011; Dahl et al. 2013; Marulcu et al. 2014; Lakin 2006; Dillon et al. 2006). Gaedicke et al. (2016) organized a summer camp for increasing student interest towards construction management and its subcomponents of science, technology, engineering, and mathematics fields. In this five days of program, he reported that students' awareness increased and they began to see construction management and engineering as an attractive career option and facilitated their transition to a college program. 
Awareness mentioned by the students was related to various fields such as areas of interest, personal development, social communication and professions. Ayar et al. (2013) found that at their camp program students realized the nature of engineering work contains problems and solutions to generate and use. The camp also served as a platform for the students, who are about to enter the university, to determine their career choices in the engineering fields as a result of the camp organized on robotics at a university. In short, their awareness about their choices became increased and their mindsets differentiated. Students said: "Although I am one of math-natural sciences student, forensic psychology (This profession is included in linguistic-math sciences) appealed to me. I am now thinking of to choose linguistic-math sciences indeed I am confused." S13, "I saw that I am good at dancing and I think I take it up. I was afraid that I could not make any friends but I did..." S9, "I learned how use my brain actively and how to plan. Also, I saw that I could manage how to plan my life and implement it without my family." S7.

\section{Program Staff}

Among the reasons why the students loved some courses, the most effective ones are the interest for the course, expectations about the course and the attitudes of the professors. It can be claimed that helping students discover their own interests and take related courses can ease their orientation to that field. In the literature, it was found in different studies that smart and professors have a big influence on students (Fields 2009; Tekbiyik et al. 2013; Dahl et al. 2013; Sozer 2013). In fact, having student-centered beliefs and being constructivist in teaching reflect upon positively in-class practical orientations (Soysal\& Radmard, 2017). The analysis of the data revealed that most of the students touched upon the positive attitudes all program staff from professors to the organizers or etc. S11 said: "Here, I saw a university environment for the first time, this is already a perfect experience all by itself. I also met people from different high schools. Besides, I had the chance of talking to specialists in different fields." S34 said: "The attitudes of program staff taking care of us made me relax and I could understand that the priority was us." S1 said: "...professors really took care of us. The best feature of the camp was the attitudes of the professors and organizers since they both were nice and gave the impression that they enjoyed being with us." S13: "The professors and organizers was so caring that I was very pleased." S22: "It was amazing for me that the organizers working time from 9 a.m. to 24.00 p.m. It really required devotion. I hoped they could get in return and thanks to everyone who cared us for two weeks."

\section{SUGGESTIONS}

\section{Suggestions from students}

Students stated that the number of the courses, diversity of the courses and the class hours should be increased. The seminars and activities taken place at university should be continued also in the dormitory during the summer camp program. They underlined that they would like to take responsibilities in and out of the campus; they would like go to the class without the guidance of program staff and plan their own free time.

\section{Suggestions from the researcher}

The effects of students' views can be evaluated in the long run. Such a study should be conducted for Grade 9 students before they choose their working spaces in high schools. Also in this kind of studies, one the aim should be to improve communication and teamwork skills that handled as professional working areas. It can be suggested that such programs can be organized for all students at high school level. Students' skills should be tested and in line with the test results, new programs can also be developed for gifted and talented students.

\section{REFERENCES}

Allen, K., Akinyanju, K., Milliken, T., Lorek, E., \& Walker, T. T. (2011). Improving the pro-social skills of transitioning urban youth: A summer camp approach. Middle School Journal, 42(4), 14-22. doi:10.1080/00940771.2011.11461770.

Alvarez, I. J. B. (2017). Introduction to Robotics: Importance of a Summer Camp as a Recruiting Tool for Future University Students." IEEE Revista Iberoamericana de Tecnologias del Aprendizaje.

Antink-Meyer, A., Bartos, S., Lederman, J. S., \& Lederman, N. G. (2016). Using Science Camps To Develop Understandings About Scientific Inquiry - Taiwanese Students In A Us Summer Science Camp. International Journal of Science and Mathematics Education, 14(1), 29-53.

Ayar, M., Yalvac, B., Uğurdă̆, H. F., \& Şahin, A. (2013). A robotics summer camp for high school students: pipelines activities promoting careers in engineering fields. In 2013 ASEE Annual Conference. American Society for Engineering Education. 
Bandura, A. (1987). Self-regulation of motivation and action through goal systems. In V. Hamilton, G. H. Bower, \& N. H. Frijda (Eds.), Cognitive perspectives on emotion and motivation 37 -61. Dordrecht, The Netherlands: Kluwer.

Bean, C. N., Kendellen, K., \& Forneris, T. (2016). Examining needs support and positive developmental experiences through youth's leisure participation in a residential summer camp. Leisure/Loisir, 40(3), 221-295.

Bhattacharyya, S., Mead, T. P., \& Nathaniel, R. (2011). The influence of science summer camp on African-American high school students' career choices. School Science and Mathematics, 111(7), 345-353. doi:10.1111/j.19498594.2011.00097.x

Buskirk-Cohena, A. (2015). Effectiveness of a creative arts summer camp: benefits of a short-term, intensive program on children's social behaviors and relationships. Journal of Creativity in Mental Health, 10, 34-45. doi:10.1080/15401383.2014.946637

Celik, I. (2012). Bir bilim kampından notlar. TUBITAK Bilim ve Teknik Dergisi, 538, 15-19.

Ciloglugil, B., Aslan, B. G., \& İnceoglu, M. M. (2017). Lise Öğrencilerine Bilgisayar Donanımı Öğretimi: Devremi Kuruyorum. Ege Egitim Dergisi, 18(1), 266-287.

Dahl, T. I., Sethre-Hofstad, L., \& Salomon, G. (2013). Intentionally designed thinking and experience spaces: What we learned at summer camp. Learning Environments Research, 16(1), 91-112. doi:10.1007/s10984-012-9124-4

Das, D. M. K. (1997). A Novel Summer Camp for The Underrepresented Minority High School Students. Paper presented at 1997 Annual Conference, Milwaukee, Wisconsin.

Dillon, J., Rickinson, M., Teamey, K., Morris, M., Choi, M. Y., Sanders, D., \& Benefield, P. (2006). The value of outdoor learning: evidence from research in the UK and elsewhere. School science review, 87(320), 107.

Doerschuk, P., Liu, J., \& Mann, J. (2007). Pilot summer camps in computing for middle school girls. SIGCSE Bull. ACM SIGCSE Bulletin, 39(3), 4. doi:10.1145/1269900.1268789

Downey, J., Bartczak, S., Young, P., \& England, E. (2016). An Eight-year Study of the Influence of IT Career Camps on Altering Perceptions of IT Majors and Careers. Communications of the Association for Information Systems, 38. Article Available at: http://aisel.aisnet.org/cais/vol38/iss1/1

Es, H. (2016). The effects of children's university activities on children's views and attitudes towards scientists and science. International Journal of Learning and Teaching, 8(2), 100-108.

Fields, D. A. (2009). What do students gain from a week at science camp? Youth perceptions and the design of an immersive, research-oriented astronomy camp. International Journal of Science Education, 31(2), 151-171. doi:10.1080/09500690701648291

Foster, J. S., \& Shiel-Rolle, N. (2011). Building scientific literacy through summer science camps: a strategy for design. Implementation and Assessment. Science Education International, 22(2), 85-98.

Gaedicke, C., Shahbodaghlou, F., Guiney, D. (2016). Promoting Construction in K-12 STEM Education Through an Innovative University-based Summer Camp. 52 nd ASC Annual International Conference Proceedings Promoting Construction in K-12 STEM Education Through an Innovative University-based Summer Camp. Conference Paper.

Gerhart, A. L., \& Carpenter, D. D. (2014). Creativity, innovation, and ingenuity summer enrichment programCollaborating with a cultural institution and preliminary assessment. In Frontiers in Education Conference (FIE), 2014 IEEE (pp. 1-5). IEEE.

Hany, E. A., \& Grosch, C. (2007). Long-Term Effects of Enrichment Summer Courses on the Academic Performance of Gifted Adolescents. Educational Research and Evaluation: An International Journal on Theory and Practice, 13, 6, 521-537.

Helm, E. G., Parker, J. E., \& Russell, M. C. (1999). Education and career paths of LSU's summer science program students from 1985 to 1997. Academic Medicine, 74(4), 336-48. doi:10.1097/00001888-199904000-00017

Hırça, N. (2013). Gifted students' summer science camp experiences. Journal of Gifted Education Research, 1(1), 22-30.

Knox, K. L., Moynihan, J. A., \& Markowitz, D. G. (2003). Evaluation of short-term impact of a high school summer science program on students' perceived knowledge and skills. Journal of Science Education and Technology, 12(4), 471-78. doi:10.1023/b:jost.0000006306.97336.c5

Konur, B., K., Seyihoglu, A., Sezen, G., \& Tekbiyik, A. (2011). Bir bilim kampı uygulamasının değerlendirilmesi: Gizemli dünyanın eğlenceli keşfi. Kuram ve Uygulamada Eğitim Bilimleri, 11(3), 1589-608.

Lakin, L. (2006). Science beyond the classroom. Journal of Biological Education, 40(2), 89-90.

Markowitz, D. G. (2004). Evaluation of the long-term impact of a university high school summer science program on students' interest and perceived abilities in science. Journal of Science Education and Technology, 13(3), 395407. doi:10.1023/b:jost.0000045467.67907.7b 
Martinez, D., \& Hibbs, M. (2003). Using summer camps to motivate rural students in science and engineering. 33rd Annual Frontiers in Education. doi:10.1109/fie.2003.1264704

Marulcu, İ., Saylan, A., \& Güven, E. (2014). 6. ve 7. sınıf öğrenciler için gerçekleştirilen 'küçük bilginler bilim okulu'nun değerlendirilmesi. Mustafa Kemal Üniversitesi Sosyal Bilimler Enstitüsü Dergisi, 11(25).

Merriam, S. B. (1998). Qualitative research and case study applications in education. San Francisco: Jossey-Bass.

Richards, E. W. (2011). Social and musical objectives or experiences school music teachers anticipate their students will achieve as a result of attending a summer music camp. Contributions to Music Education, 61-72.

Saß, H., Wittchen, H.U., \& Zaudig, M. (1996). Diagnostisches und statistisches Manual psychischer Storungen. DSM-IVDiagnostic and Statistical Manual of Mental Disorders, DSM-IV. Gottingen, Germany: Hogrefe.

Savenye, W. C., \& Robinson, R. S. (1996). Qualitative research issues and methods: An introduction for educational technologists. Handbook of research for educational communications and technology, 1171-1195.

Saxon, J. A., Treffinger, D. J., Young, G. C., \& Wittig, C. V. (2003). Camp Invention ${ }^{\circledR}$ : A creative, inquiry-based summer enrichment program for elementary students. The Journal of Creative Behavior, 37(1), 64-74. doi:10.1002/j.2162-6057.2003.tb00826.x

Shabi, M., \& Ansari, W. W. (2001). Leaders' perceptions of youth identity in a summer camp in the united kingdom: A qualitative enquiry. European Judaism, 34(1), 142-57. doi:10.3167/001430001782385044

Shiever, S., \& Maker, C. J. (2003). New Directions İn Enrichment And Acceleration. In N. Colengelo \& G. A. Davis (Eds.) Handbook of Gifted Education, pp. 163-173. Boston: Allyn \& Bacon.

Smith, E. F., Steel, G., \& Gidlow, B. (2010). The temporary community: Student experiences of school-based outdoor education programmes. Journal of Experiential Education, 33(2), 136-150. doi:10.5193/jee33.2.136

Sowells, E., Waller, L., Ofori-Boadu, A., \& Bullock, G. (2016, September). Using technology summer camp to stimulate the interest of female high school students in technology careers. In Management of Engineering and Technology (PICMET), 2016 Portland International Conference on (pp. 1688-1696). IEEE.

Soysal, Y., \& Radmard, S. (2017). Social negotiations of meanings and changes in the beliefs of prospective teachers: A vygotskian perspective. Educational Studies, 1-24.

Sözer, Y. (2013). Doğada gerçekleştirilen bir matematik yaz kampının lise öğrencileri üzerindeki etkilerinin öğrenci görüşlerine göre incelenmesi. Adnan Menderes Üniversitesi Ĕ̆itim Fakültesi, 4(2), 1-18.

Tekbiyik, A., Seyihoglu, A., Sezen Vekli, G., \& Birinci Konur, K. (2013). Aktif öğrenmeye dayalı bir yaz bilim kampının öğrenciler üzerindeki etkilerinin incelenmesi. The Journal of Academic Social Science Studies (JASSS), 6(1), 1383-406.

Vekli, G. S. (2013). Summer science camp for middle school students: A Turkish experience. In Asia-Pacific Forum on Science Learning and Teaching, 14(1), 1-26.

Westervelt, D. V., Johnson, D. C., Westervelt, M. D., \& Murrill, S. (1998). Changes in self-concept and academic skills during a multimodal summer camp program. Annals of Dyslexia Ann. of Dyslexia, 48(1), 189-212. doi:10.1007/s11881-998-0009-2

\section{http://www.ejmste.com}

